Brazilian Journal

of Chemical

Engineering

\title{
EVALUATION OF ANTIOXIDANT ACTIVITY OF NATURAL EXTRACTS ON THE OXIDATIVE STABILITY OF COTTONSEED BIODIESEL
}

\author{
João P. A. Freitas ${ }^{1 *}$, Fernanda R. M. França ${ }^{2}$, Maria S. Silva ${ }^{3}$, \\ Richard J. Toms ${ }^{4}$ and Gabriel F. da Silva ${ }^{5}$ \\ ${ }^{1}$ Universidade Federal de Sergipe, Departamento de Engenharia Química, Aracaju, SE, Brasil. E-mail: jp_a_f@outlook.com - \\ ORCID: 0000-0003-0255-7104 \\ ${ }^{2}$ Universidade Federal de Alagoas, Departamento de Engenharia Química Maceió, AL, Brasil. \\ ${ }^{3}$ Universidade Federal de Sergipe, Departamento de Engenharia Química, Centro de Pesquisa de Petróleo e Gás, Aracaju, SE, Brasil. \\ ${ }^{4}$ University of Surrey, Centre for Environment and Sustainability, Surrey, United Kingdom. \\ ${ }^{5}$ Universidade Federal de Sergipe, Departamento de Engenharia Química, Laboratório de Tecnologias Alternativas, Aracaju, SE, Brasil.
}

(Submitted: July 4, 2018 ; Revised: September 19, 2018 ; Accepted: October 4, 2018)

\begin{abstract}
The objective of this study was to evaluate the antioxidant activity of the natural extracts catechin, curcumin and quercetin on the oxidative stability of methylic cottonseed oil biodiesel. The oxidative stability was evaluated using the Rancimat method (EN 14112) for biodiesel with 500, 1000, 1500, 2000 and 3000 ppm of additives, and compared with the commercial antioxidant butyl hydroxyanisole at the same concentrations. Kinematic viscosity was also evaluated at the same concentration. All additives had a positive effect on the oxidative stability; moreover, all extracts presented better results than BHA. Catechin was the most effective additive, achieving an induction period almost three times greater than BHA for $3000 \mathrm{ppm}$. In addition, all three extracts caused a reduction in kinematic viscosity, but it remained within the technical specification. These results prove catechin, curcumin and quercetin to be powerful natural antioxidants.
\end{abstract}

Keywords: Antioxidant; Biodiesel; Oxidative stability.

\section{INTRODUCTION}

The long and short-term impacts of using nonrenewable sources of energy have driven a remarkable advance in the use of sustainable sources of energy, such as biodiesel. Biodiesel is a renewable, biodegradable and non-toxic fuel generally produced by the transesterification reaction of vegetable oils with shortchain alcohols in the presence of a catalyst (Albuquerque et al., 2009). Even though many of its properties resemble those of petrodiesel, some of them are off specification, such as oxidative stability (Knothe et al., 2010).

Unlike diesel, biodiesel is susceptible to oxidation when exposed to oxygen, which directly affects fuel quality. This phenomenon is best known as autooxidation, and can have a significant economic and technical impact due to the corrosion of engine parts, and the formation of lees that can obstruct the injection system (BiodieselBR, 2015). The oxidative process is related to the presence of double bonds in the molecules of the various fatty acids that compose biodiesel, and the position they are located in the molecules: bis-allylic bonds are more susceptible to self-oxidation than allylic bonds (Knothe et al., 2010).

To reduce the oxidative process, antioxidant additives are used commercially, which act to neutralize or scavenge free radicals formed during the oxidation reaction, creating more stable intermediates and, consequently, reducing the oxidative process (Sousa et al., 2007). Antioxidants can be synthetic or natural. In general, synthetic additives have higher antioxidant activity, due to their higher purity in comparison to

\footnotetext{
* Corresponding author: João P. A. Freitas - E-mail: jp_a_f@outlook.com
} 
natural additives; yet, conversely, they are toxic and non-biodegradable. Studies related to the use of natural antioxidants are of great importance, informing how to make biodiesel an even more sustainable and less polluting source of energy (Pereira et al., 2012; Sousa et al., 2014). There are many types and sources of natural antioxidants; however, it is necessary to purify these components in order to maximize the antioxidant activity. Tocopherols, ascorbic acid, carotenes, catechins, curcuminoids and quercetin are just some examples of natural antioxidants.

Catechin is a colorless, water-soluble compound that belongs to a group of polyphenols that are powerful antioxidants and free metal scavengers (Du et al., 2012; Matsubara and Rodriguez-Amaya, 2006). There are five types of catechin (Figure 1), all of them comprising a similar chemical structure that enables them to stabilize free radicals and inhibit oxidative process. The main sources of catechins are green tea, dark chocolate, blackberries and black tea.(SFGate, 2017).

Regarding biofuels, the use of catechins as an additive is scarce. Studies have identified their presence in moringa plant extracts to be used as antioxidant additives in biodiesel (França et al., 2014). However, despite the acknowledgement of such substances in plant extracts and their high antioxidant potential, the use of catechins as an oxidative process inhibitor in biodiesel has not yet been reported in the literature.

Curcumin is a yellow pigment that occurs naturally in Curcuma long a L. and, in its powdered form, is better known as turmeric (Borra et al., 2013). It is composed<smiles>Oc1cc(O)c2c(c1)O[C@H](c1ccc(O)c(O)c1)[C@H](O)C2</smiles>

Simple catechin<smiles>CC(C)CCCCC(C)C(C)C</smiles><smiles>Oc1cc(O)c2c(c1)O[C@H](c1cc(O)c(O)c(O)c1)[C@H](O)C2</smiles>

Epigallocatechin<smiles>O=C(O[C@H]1Cc2c(O)cc(O)cc2O[C@H]1c1ccc(O)c(O)c1)c1cc(O)c(O)c([18OH])c1</smiles>

Epicatechin gallate



Epigallocatechin gallate
Figure 1. Molecular structure of the five types of catechin. of curcumin (59-71\%), demethoxycurcumin (25-29\%) and bisdemethoxycurcumin (4-12\%) (Figure 2) (PéretAlmeida et al., 2008), all of them with antioxidant activity. Due to their phenolic nature, curcuminoids have been studied as antioxidant additives in various systems (Sueth-Santiago et al., 2015). Their use in biodiesel has been little reported, although the antioxidant potential has already been proven (Sousa et al., 2014).

Quercetin (Figure 3) is a natural flavonoid present in plants and fruits that gives them color and taste (Park, 2010). It is one of the flavonoids most present in the human diet (about 95\%) and it can be found in onions, broccoli and apples (Mlcek et al., 2016; Sociedade Brasileira de Química, 2016). Its phenolic structure gives it great antioxidant potential, due to four hydroxyl substituents distributed in its aromatic rings (Figure 3). Although there are few studies on the antioxidant activity of quercetin, one can infer, by its molecular structure, that its antioxidant power can also be used in biofuels (Lima et al., 2013). Additionally, quercetin has been successfully used in living organisms as an antioxidant (Gerin et al., 2016; Kobori et al., 2015; Sá et al., 2012; Yamaguchi et al., 2012). Studies using plant extracts have already reported the presence of quercetin in moringa and radish extracts (Devaraj et al., 2011; Govardhan Singh et al., 2013). Its use to inhibit oxidation in vegetable oils has also been reported (Kowalski, 2010). Despite


Demethoxycurcumin

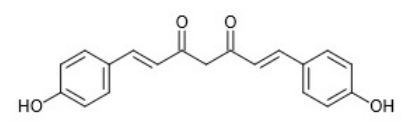

Bisdemethoxycurcumin

Figure 2. Molecular structure of the main curcuminoids in Curcuma longa L.<smiles>O=C1C(O)=C(c2ccc(O)c(O)c2)Cc2cc(O)cc(O)c21</smiles>

Figure 3. Molecular structure of quercetin. 
this evidence, its use as an antioxidant for biodiesel has not yet been explicitly documented.

Thus, despite the scarcity of studies on the application of these extracts in biodiesel, the results presented so far suggest that all three of the aforementioned extracts show great potential to be used as an additive to improve biodiesel oxidative stability, and to replace synthetic antioxidants. However, studies are needed to prove its effectiveness and, thus, make biodiesel an even more sustainable and less polluting source of energy.

The objective of this study was to evaluate the antioxidant potential of catechin, curcumin and quercetin to improve oxidative stability of methylic cottonseed oil biodiesel compared to the commercial synthetic antioxidant butyl hydroxyanisole (BHA). In addition, the kinematic viscosity was also monitored to assess the extracts influence on this property.

\section{EXPERIMENTAL}

\section{Biodiesel synthesis}

The conditions used for the synthesis of cottonseed oil biodiesel were based on the study of Onukwuli et al. (2017). Cottonseed oil was obtained in the local market. For the conventional transesterification reaction, a 6:1 methanol/oil molar ratio was used with $0.6 \%$ (mass) of $\mathrm{KOH}$ as the catalyst. Initially, $\mathrm{KOH}$ was dissolved in methanol to form potassium methoxide. Thereafter, the mixture was slowly added to the cottonseed oil already under stirring (300rpm) at $55^{\circ} \mathrm{C}$. After one hour, the mixture was transferred to a separating funnel to promote phase separation until the interface became clear; the dark phase (glycerin) was at the bottom, and the clear phase (biodiesel) at the top. Then, glycerin was removed and the biodiesel was washed with ultrapure water at $90^{\circ} \mathrm{C}$ to remove the catalyst. Finally, the biofuel was heated to $100{ }^{\circ} \mathrm{C}$ for 3 hours to evaporate the remaining water from the washing process

\section{Biodiesel characterization}

Acid value: The analysis was performed according to NBR 14448.

Oxidative stability at $110^{\circ} \mathrm{C}$ : The tests were carried out according to European standard EN 14112 using a Rancimat model 873 by Metrohm at $110^{\circ} \mathrm{C}$.

Kinematic viscosity at $40^{\circ} \mathrm{C}$ : The kinematic viscosity analysis was performed according to ASTM
D445 in a kinematic viscometer using a Cannon Fenske type capillary. The same methodology was carried out to measure the kinematic viscosity of the biodiesel additivated with the extracts at the same concentrations of the oxidative stability tests.

Moisture content: The moisture content was measured according to ASTM D6304.

Cold flow plugging point (CFPP): CFPP analysis was performed according to ASTM D6371 using a FPP 5Gs automatic analyzer by ISL.

\section{Antioxidants}

The three natural extracts used in this study were obtained in a local compounding pharmacy to ensure high purity: catechin with a purity of $72.7 \%$, of which $52.6 \%$ are epigallocatechin gallate, the most powerful antioxidant among the catechins; curcumin with $96.68 \%$ of curcuminoids; and quercetin with a purity of $97.22 \%$, all produced by Florien. The catechin used in this study was in the form of GreenSelect ${ }^{\circledR}$, a registered Florien product.

\section{Oxidative stability tests}

The process described under the Experimental subsection "Oxidative stability" was carried out for pure biodiesel and biodiesel added with catechin, curcumin, quercetin and BHA individually at the concentrations of 500,1000,1500, 2000 and 3000 ppm at $110^{\circ} \mathrm{C}$. The compounds were added to the biodiesel at room temperature and then agitated using a magnetic stirrer for 5 minutes. All measurements were done in triplicates.

\section{RESULTS AND DISCUSSION}

\section{Biodiesel characterization}

The results obtained from the biodiesel characterization are presented in Table 1. According to Table 1, one can observe that the kinematic viscosity of the synthesized biodiesel is within the range established by Brazilian law (Brasil, 2014). This property is very important for fuels, because it affects the biodiesel atomization in the combustion chamber. In addition, the higher the viscosity, the greater the tendency to form deposits inside the engine, which may also affect the injection system (Gondim, 2009; Lôbo et al., 2009).

The result for the acid value is in accordance with the technical specification. This property is an

Table 1. Results of the characterization of the biodiesel.

\begin{tabular}{cccc}
\hline Property & Result & Specification (Brasil, 2014) & Unit \\
\hline Kinematic viscosity at $40^{\circ} \mathrm{C}$ & 4.69 & $3.5-6.0$ & $\mathrm{~mm}^{2} / \mathrm{s}$ \\
Acid value & 0.14 & 0.5 (maximum) & $\mathrm{mgKOH}_{\mathrm{gbiodiesel}}$ \\
Moisture content & 6.80 & 200 (maximum) & $\mathrm{mg} / \mathrm{kg}$ \\
Oxidative stability at $110^{\circ}$ & 4.68 & 8 (minimum) & $\mathrm{h}$ \\
CFPP & 5 & See Table 2 & ${ }^{\circ} \mathrm{C}$ \\
\hline
\end{tabular}


important characteristic of biodiesel, related to its age; the older the biodiesel, the higher the concentration of acids produced by the oxidative process, which can corrode the engine and the fuel tank (Engineers Edge, 2016). This is another property influenced by antioxidants.

The moisture content was much lower than the maximum allowed by law. This result is significant for biodiesel, as water can cause hydrolysis (undesired reaction) and produce free fatty acids, which can damage the engine (Silva, 2011). In addition, water accelerates the oxidative process and damages the injection system due to deposit formation (BiodieselBR, 2015).

The result for oxidative stability was below the minimum value required by law, which was already expected. This fact is mainly due to the unsaturated bonds present in the fatty acids that constitutes the biofuel, which are derived from the vegetable oil used to produce the biodiesel. Due to the low oxidative stability, it is necessary to use antioxidant additives to improve such property. On the other hand, although it is not in accordance with the specification, the oxidative stability of the synthesized biodiesel is still higher than biodiesels from other sources such as soybean, karanja (Pongamia pinnata), jatropha (Jatropha curcas L.) and other cottonseed biodiesels reported in the literature (Dwivedi and Sharma, 2016; Rawat et al., 2015; Roveda et al., 2016; Serqueira et al., 2015; Serqueira et al., 2014).

Regarding CFPP, the result is also in accordance with Brazilian specifications (Brasil, 2014) (Table 2 ), and it is even better than mahua (Shorea robusta) and palm (Elaeis guineenses) biodiesels, for example (Acharya et al., 2017; Sierra-Cantor and GuerreroFajardo, 2017). Even though CFPP is higher than biodiesels derived from other sources, such as coconut and corn, the biodiesel synthesized can be used in all seasons and in all Brazilian states, including the southern region, where the maximum CFPP allowed is the lowest value among all states $\left(5^{\circ} \mathrm{C}\right)$ (Rasimoglu and Temur, 2014; Sierra-Cantor and Guerrero-Fajardo, 2017). This result ensures that the biofuel performance will not be compromised even when used in the colder Brazilian states.

\section{Antioxidant activity of extracts}

All extracts had a positive effect on the oxidative stability of biodiesel, as well as the synthetic antioxidant BHA. The results are presented in Figure 4. One can observe that the four additives reached the minimum value for oxidative stability required by law at $1000 \mathrm{ppm}$. However, whereas BHA was at the lower limit, curcumin, quercetin and catechin exceeded more than $10 \%, 20 \%$ and $50 \%$, respectively, the minimum specifications. This result shows that catechin, curcumin and quercetin require lower concentration to achieve the minimum value for oxidative stability in comparison to BHA, especially for catechin. Such inference is confirmed by increasing the concentration of the additives.

In general, by increasing the antioxidant concentration, oxidative stability is also raised. Catechin was the most efficient among all four additives, followed by quercetin, curcumin and BHA. This result is consistent with their chemical structures: the presence of activating groups (electron donors), hydroxyl groups for example, ortho and/or para to the hydroxyl group of phenol enhances the antioxidant activity of the compound by an inductive effect. Thus, the more electronegative the substituent, the greater the inductive effect in benefit of the antioxidant activity. Moreover, branched alkyl groups ortho to the hydroxyl group of phenol decrease the antioxidant activity, since they enable the molecule to create a stable resonance structure that makes it difficult for the antioxidant to participate in the propagation reactions of the oxidative process (Wanasundara and Shahidi, 2005). Therefore, in addition to BHA having the lowest number of hydroxyl groups among the additives used, it has a branched alkyl radical ortho to

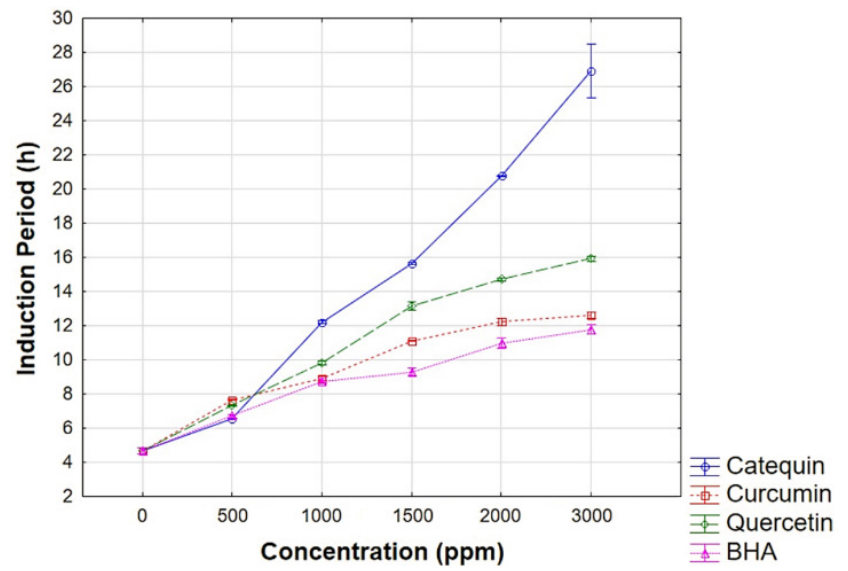

Figure 4. Biodiesel induction period for different concentrations of additives.

Table 2. Maximum values of the CFPP for each Brazilian state and month. Other states must consider $19^{\circ} \mathrm{C}$ for all months.(Brasil, 2014).

\begin{tabular}{|c|c|c|c|c|c|c|c|c|c|c|c|c|}
\hline \multirow{2}{*}{ State } & \multicolumn{12}{|c|}{ Maximum value $\left({ }^{\circ} \mathrm{C}\right)$} \\
\hline & Jan & Feb & Mar & Apr & May & Jun & Jul & Aug & Set & Oct & Nov & Dec \\
\hline SP, MG, MS & 14 & 14 & 14 & 12 & 8 & 8 & 8 & 8 & 8 & 12 & 14 & 14 \\
\hline GO, DF, MT, ES, RJ & 14 & 14 & 14 & 14 & 10 & 10 & 10 & 10 & 10 & 14 & 14 & 14 \\
\hline PR, SC, RS & 14 & 14 & 14 & 10 & 5 & 5 & 5 & 5 & 5 & 10 & 14 & 14 \\
\hline
\end{tabular}


the hydroxyl group of phenol (Figure 5) that reduces its antioxidant activity. Catechin, on the other hand, besides having the largest number of hydroxyl groups attached to the ring, also has some of them ortho to the hydroxyl group of phenol (Figure 1) that increases its antioxidant activity.

For concentrations higher than 1000 ppm of BHA, the oxidative stability stayed practically constant. The same behavior has also been also reported in the literature (Yang et al., 2017). This phenomenon can be attributed to a possible limit of BHA solubility in cottonseed biodiesel, in which, for concentrations above 1000 ppm, the antioxidant does not completely solubilize, reducing the donation of hydrogens to the radicals formed in the oxidative process. However, additional studies are necessary to determine the veracity of this hypothesis.<smiles>COc1ccc(O)c(C(C)(C)C)c1</smiles>

Figure 5. BHA's molecular structure.

\section{Influence of additives on kinematic viscosity}

The results presented in Figure 6 show a trend of decline in kinematic viscosity with increasing concentration for all extracts studied. The maximum reduction was achieved at 3000 ppm for all additives: $10.66 \%, 10.23 \%$ and $7.03 \%$ for catechin, curcumin and quercetin, respectively.

Even though quercetin had the greater effect on the kinematic viscosity for the initial concentration, it showed the slightest reduction tendency. Curcumin, despite being less effective than quercetin for the first and second concentrations and less effective than catechin in nearly all conditions, showed the most significant reduction tendency in kinematic viscosity, so that it achieved an equivalent effect to that of



Figure 6. Kinematic viscosity reduction tendency caused by the addition of extracts. catechin for the highest concentration. Catechin was the most efficient extract among those studied.

It is important to emphasize that, even after the extracts were added, the biodiesel remained in accordance with Brazilian technical specifications (Brasil, 2014). Moreover, the addition of the extracts in cottonseed biodiesel contributes positively to the reduction of its kinematic viscosity, even if not very pronounced. Therefore, it reduces the formation of deposits inside the engine by improving the biofuel atomization (Gondim, 2009; Lôbo et al., 2009).

\section{CONCLUSIONS}

This study assessed the antioxidant activity of catechin, curcumin and quercetin on methylic cottonseed oil biodiesel. The antioxidant activity of the three extracts was higher than that of BHA for all conditions tested, with emphasis on catechin that achieved an induction period almost three times higher than that of BHA for 3000 ppm. In addition, although all the additives reached the minimum oxidative stability required by law at 1000 ppm, it is possible to achieve such compliance with lower concentrations. Thus, this study proved that the extracts increase the oxidative stability of cottonseed biodiesel, and they can be sustainable substitutes for synthetic antioxidants.

Furthermore, all three extracts reduced the kinematic viscosity of the biofuel and it remained within the specifications established by Brazilian law. Although this reduction was not so pronounced, it is important to emphasize that these additives have the primary role of increasing oxidative stability, so that the reduction of kinematic viscosity is a secondary benefit.

\section{REFERENCES}

Acharya, N., Nanda, P., Panda, S., Acharya, S., Analysis of properties and estimation of optimum blending ratio of blended mahua biodiesel. Engineering Science and Technology, an International Journal, 20, 511-517 (2017). https://doi.org/10.1016/j. jestch.2016.12.005

Albuquerque, M. C. G., Machado, Y. L., Torres, A. E. B., Azevedo, D. C. S. Cavalcante Jr., C. L., Firmiano, L. R., Parente Jr., E. J. S., Properties of biodiesel oils formulated using different biomass sources and their blends. Renewable Energy, 34, $857-859$ (2009). https://doi.org/10.1016/j.renene.2008.07.006

BiodieselBR, Moringa pode virar aditivo antioxidante para biodiesel (2015).

Borra, S.K., Gurumurthy, P., Mahendra, J., Jayamathi, K. M., Cherian, C. N., Chand, R. Antioxidant and free radical scavenging activity of curcumin determined by using different in vitro and ex vivo models. Journal of Medicinal Plant Research, 7, 2680-2690 (2013). 
Brasil, Agência Nacional do Petróleo. Dispõe sobre a especificação do biodiesel contida no Regulamento Técnico ANP no 3 de 2014 e as obrigações quanto ao controle da qualidade a serem atendidas pelos diversos agentes econômicos que comercializam o produto em todo o território nacional. Resolução n. 45, de 28 de agosto de 2014 (2014).

Devaraj, V. C., Krishna, B. G., Viswanatha, G. L., Simultaneous determination of quercetin, rutin and kaempferol in the leaf extracts of Moringa oleifera Lam. and Raphinus sativus Linn. by liquid chromatography-tandem mass spectrometry. Zhong Xi Yi Jie He Xue Bao, 9, 1022-30 (2011). https://doi.org/10.3736/jcim20110914

Du, G.-J., Zhang, Z., Wen, X.-D., Yu, C., Calway, T., Yuan, C.-S., Wang, C.-Z., Epigallocatechin Gallate (EGCG) Is the Most Effective Cancer Chemopreventive Polyphenol in Green Tea. Nutrients, 4, 1679-1691 (2012). https://doi. org/10.3390/nu4111679

Dwivedi, G., Sharma, M. P., Investigation of Oxidation stability of Pongamia Biodiesel and its blends with diesel. Egyptian Journal of Petroleum, 25, 15-20 (2016). https://doi.org/10.1016/j.ejpe.2015.06.005

Engineers Edge, Acid Value Number or Neutralization Number of Oil (2016).

França, F. R. M., Menezes, D. S., Moreira, J. J. S., Silva, G. F., Brandão, S. T., Potencial da Moringa oleifera Lam (Moringaceae) como fonte de antioxidante natural para biocombustível, Congresso Brasileiro de Engenharia Química, Florianópolis, pp. 1-8 (2014). https://doi.org/10.5151/chemengcobeq2014-0474-25313-189089

Gerin, F., Sener, U., Erman, H., Yilmaz, A., Aydin, B., Armutcu, F., Gurel, A., The Effects of Quercetin on Acute Lung Injury and Biomarkers of Inflammation and Oxidative Stress in the Rat Model of Sepsis. Inflammation, 39, 700-705 (2016). https://doi. org/10.1007/s10753-015-0296-9

Gondim, A.D., Avaliação da estabilidade térmica e oxidativa de algodão e do efeito da adição de antioxidantes ( $\alpha$-tocoferol e BHT). Tese Thesis, Universidade Federal do Rio Grande do Norte, Natal, 247 pp. (2009)

Govardhan Singh, R. S., Negi, P. S., Radha, C., Phenolic composition, antioxidant and antimicrobial activities of free and bound phenolic extracts of Moringa oleifera seed flour. Journal of Functional Foods, 5, 1883-1891 (2013). https://doi. org/10.1016/j.jff.2013.09.009

Knothe, G., Gerpen, J. V., Krajl, J., The Biodiesel Handbook. AOCS Press, Campaign, 501 pp (2010.)

Kobori, M., Takahashi, Y., Akimoto, Y., Sakurai, M., Matsunaga, I., Nishimuro, H., Ippoushi, K., Oike, H., Ohnishi-Kameyama, M., Chronic high intake of quercetin reduces oxidative stress and induces expression of the antioxidant enzymes in the liver and visceral adipose tissues in mice. Journal of Functional Foods, 15, 551-560 (2015). https://doi. org/10.1016/j.jff.2015.04.006

Kowalski, R., Changes of linoleic acid concentration during heating of some plant-origin oils with polyphenol addition. Journal of Food Quality, 33, 269-282 (2010). https://doi.org/10.1111/j.17454557.2010.00295.x

Lima, I. R., Pedrosa, M. R. G., Pereira, C. B., Avaliação do potencial antioxidante de produtos naturais em diferentes biodieseis submetidos ao aquecimento, Simpósio Brasileiro de Educação Química, Terezina (2013).

Lôbo, I. P., Ferreira, S. L. C., Cruz, R. S., Biodiesel: parâmetros de qualidade e métodos analíticos. Química Nova, 32, 1596-1608 (2009). https://doi. org/10.1590/S0100-40422009000600044

Matsubara, S., Rodriguez-Amaya, D. B., Teores de catequinas e teaflavinas em chás comercializados no Brasil. Food Science and Technology (Campinas), 26, 401-407 (2006). https://doi.org/10.1590/S010120612006000200024

Mlcek, J., Jurikova, T., Skrovankova, S., Sochor, J., Quercetin and Its Anti-Allergic Immune Response. Molecules, 21, 1-15 (2016). https://doi. org/10.3390/molecules21050623

Onukwuli, D. O., Emembolu, L. N., Ude, C. N., Aliozo, S. O., Menkiti, M. C., Optimization of biodiesel production from refined cotton seed oil and its characterization. Egyptian Journal of Petroleum, 26, 103-110 (2017). https://doi.org/10.1016/j. ejpe.2016.02.001

Park, J. B., Quercetin. In: Coates, P. M., Blackman, M. R., Cragg, M. L., Levine, M., Moss, J., White, J. D., (Eds.), Encyclopedia of Dietary Supplements. CRC Press, London, pp. 920 (2010). https://doi. org/10.1201/b14669-77

Pereira, D. F., Silva, A. P. da, Vasconcelos, V. M., Aranda, D. A. G., Silva, G. F. da, Avaliação da estabilidade à oxidação do biodiesel a partir da moringa. Revista Tecnologia, 33, 156-164 (2012).

Péret-Almeida, L., Naghetini, C. da C., Nunan, E. de A., Junqueira, R. G., Glória, M. B. A., Atividade antimicrobiana in vitro do rizoma em pó, dos pigmentos curcuminóides e dos óleos e dos essenciais da Curcuma longa L. Ciência e Agrotecnologia, 32, 875-881 (2008). https://doi. org/10.1590/S1413-70542008000300026

Rasimoglu, N., Temur, H., Cold flow properties of biodiesel obtained from corn oil. Energy, 68, 57-60 (2014). https://doi.org/10.1016/j. energy.2014.02.048

Rawat, D. S., Joshi, G., Lamba, B. Y., Tiwari, A. K., Kumar, P., The effect of binary antioxidant proportions on antioxidant synergy and oxidation 
stability of Jatropha and Karanja biodiesels. Energy, 84, 643-655 (2015). https://doi.org/10.1016/j. energy.2015.03.024

Roveda, A. C., Comin, M., Caires, A. R. L., Ferreira, V. S., Trindade, M. A. G., Thermal stability enhancement of biodiesel induced by a synergistic effect between conventional antioxidants and an alternative additive. Energy, 109, 260-265 (2016). https://doi.org/10.1016/j.energy.2016.04.111

Sá, P. G. S., Guimarães, A. L., Oliveira, A. P. de, Siqueira Filho, J. A. de, Fontana, A. P., Damasceno, P. K. F., Branco, C. R. C., Branco, A., Almeida, J. R. G. da S., Total phenols, total flavonoids and antioxidant activity of selaginella convoluta (Arn.) spring (Selaginellaceae). Revista de Ciências Farmacêuticas Básica e Aplicada, 33, 561-566 (2012).

Serqueira, D. S., Dornellas, R. M., Silva, L. G., Melo, P. G. de, Castellan, A., Ruggiero, R., Richter, E. M., Munoz, R. A. A., Tetrahydrocurcuminoids as potential antioxidants for biodiesels. Fuel, 160, 490-494 (2015). https://doi.org/10.1016/j. fuel.2015.07.104

Serqueira, D. S., Fernandes, D. M., Cunha, R. R., Squissato, A. L., Santos, D. Q., Richter, E. M., Munoz, R. A. A., Influence of blending soybean, sunflower, colza, corn, cottonseed, and residual cooking oil methyl biodiesels on the oxidation stability. Fuel, 118, 16-20 (2014). https://doi. org/10.1016/j.fuel.2013.10.028

SFGate, Foods High in Catechins (2017).

Sierra-Cantor, J. F., Guerrero-Fajardo, C. A., Methods for improving the cold flow properties of biodiesel with high saturated fatty acids content: A review. Renewable and Sustainable Energy Reviews, 72, 774-790 (2017). https://doi.org/10.1016/j. rser.2017.01.077

Silva, T. A. R., Biodiesel de óleo residual: Produição através da transesterificação por metanólise e etanólisse básica, caracterização físico-química e otimização das condições reacionais. Tese (Doutorado em Química) Thesis, Universidade Feeral de Uberlândia, Uberlândia, 133 pp. (2011)

Sociedade Brasileira de Química, Química Nova Interativa - Quercetina (2016).

Sousa, C. M. de M., Silva, H. R. e, Vieira Jr., G. M., Ayres, M. C. C., Costa, C. L. S. da, Araújo, D. S., Cavalcante, L. C. D., Barros, E. D. S., Araújo, P. B. de M., Brandão, M. S., Chaves, M. H., Fenóis totais e atividade antioxidante de cinco plantas medicinais. Química Nova, 30, 351-355 (2007). https://doi. org/10.1590/S0100-40422007000200021

Sousa, L. S., Moura, C. V. R., Oliveira, J. E., Moura, E. M., Use of natural antioxidants in soybean biodiesel. Fuel, 134, 420-428 (2014). https://doi. org/10.1016/j.fuel.2014.06.007

Sueth-Santiago, V., Mendes-Silva, G. P., DecotéRicardo, D., Lima, M. E. F., Curcumina, o pó dourado do açafrão-da-terra: Introspecções sobre química e atividades biológicas. Química Nova, 38, 538-552 (2015).

Wanasundara, P. K. J. P. D., Shahidi, F., Antioxidants: Science, Technology, and Applications. In: Shahidi, F. (Ed.), Bailey's industrial oil \& fats products. Wiley-Interscience, New Jersey, pp. 431489 (2005). https://doi.org/10.1002/047167849X. bio002

Yamaguchi, K. K. L., Alcântara, J. M., Veiga Junior, V. F., Investigação do potencial antioxidante e anticolinesterásico de 20 espécies da família Lauraceae. Acta Amazonica, 42, 541$546 \quad$ (2012). https://doi.org/10.1590/S004459672012000400012

Yang, J., He, Q. S., Corscadden, K., Caldwell, C., Improvement on oxidation and storage stability of biodiesel derived from an emerging feedstock camelina. Fuel Processing Technology, 157, 90-98 (2017). https://doi.org/10.1016/j. fuproc.2016.12.005 
